\title{
高等学校 教科「情報」の実際
}

\section{"Information Studies" in senior high school}

小原 格 ${ }^{1}$

\section{OHARA Tsutomu}

1 東京都立町田高等学校（广194-0021 東京都町田市中町4-25-3） E-Mail：ohara@johoka.info 1 Machida Metropolitan Senior High School (4-25-3 Nakamachi Machida-shi, Tokyo 194-0021)

1. はじめに

平成15年より高等学校において新教科「情報」 が始まり，今年で6年目を迎えた。「新教科」とし ての黎明期は過ぎ，そろそろ教科としての定着期 に入らなければならない状況にあるようにも思わ れるのだが，実際にはいろいろな難しい状況を抱 えているのが現状である。

筆者はスタートの年である平成15年より東京都 立町田高等学校（以下「本校」という）で教科「情 報」の専任教員として指導に当たっている。この 稿では，主に普通教科「情報」について，その科 目亡内容，具体的な授業内容，授業の工夫，課題 等について述べていきたい。

\section{2. 教科「情報」の構成と内容}

\section{1 教科「情報」の科目とその内容}

普通教科「情報」には3つの科目「情報A」「情報 B」「情報C」があり，各2単位（週2時間）である。 また，それぞれ「情報活用の実践力」「情報の科学 的な理解」「情報社会に参画する態度」が重点に置 かれているが，ここで押さえておきたいことは，こ
の3科目のいずれも，これらの3つの観点を育成で きるように構成されている，ということである。例 えば情報Bであれば，「情報の科学的な理解」を通 して情報活用の実践力を高める効果的な方法を学 び，また情報社会を支える技術のあり方について 考える，といつた形である。このように「3つの観 点が互いに関連しながら，総合的に『情報化の進 展に主体的に対応できる能力と態度』を育ててい く」という考え方が重要となっている（図1）。

専門教科「情報」は，「システム設計・管理分野」 「共通分野」「マルチメディア」の3つの分野にわた り11科目で構成されている。ここでは，「工業高

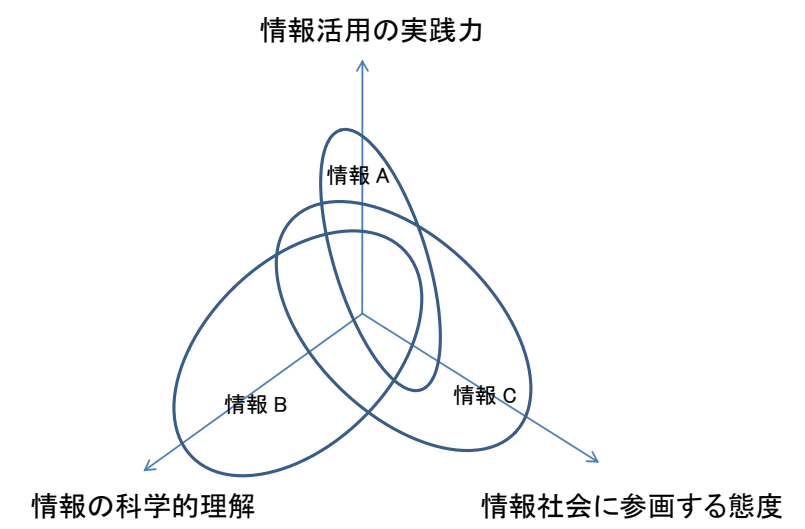

図1３つの観点と情報ABCそれぞれの大まかな位置関係 
表1＼cjkstart専門教科「情報」の科目編成（学習指導要領解説 1より）

\begin{tabular}{|c|c|c|c|}
\hline 分野 & $\begin{array}{l}\text { システム設計· } \\
\text { 管理分野 } \\
\end{array}$ & 共通分野 & マルチメディア分野 \\
\hline 基礎的科目 & & $\begin{array}{l}\text { 「情報産業と社会」 } \\
\text { 「情報と表現」 }\end{array}$ & \\
\hline 応用選択的科目 & $\begin{array}{l}\text { 「アルゴリズム」 } \\
\text { 「情報システムムの開発」 } \\
\text { 「ネットワークシステム」 }\end{array}$ & $\begin{array}{l}\text { 「モデル化と } \\
\text { シミュレーション」 }\end{array}$ & $\begin{array}{l}\text { 「コンピュータデザイン」 } \\
\text { 「図形と画像の処理」 } \\
\text { 「マルチメ゙ィア表現」 }\end{array}$ \\
\hline 総合的科目 & & $\begin{array}{l}\text { 「課題研究」 } \\
\text { 「情報実習」 }\end{array}$ & \\
\hline
\end{tabular}

校」「商業高校」のような「情報高校」が想定され ており，「情報の各分野に関する基礎的・基本的な 知識と技術を習得させる」「現代社会における情報 の意義や役割を理解させる」「高度情報通信社会の 諸課題を主体的, 合理的に解決し, 社会の発展を 図る創造的な能力と実践的な態度を育てる」とい うことがねらいとされている(表1)。

普通教科「情報」は，必履修，すなわち「情報 $\mathrm{A} 」 「$ 情報B」「情報C」のどれか1つは必ず履修しな ければならない教科となっている。つまり「高校 生の誰もが身につけておくべき」内容であり，ど ちらかというとエンドユーザーの視点である。反 面, 専門教科「情報」では, 職業に関する学科と いうこともあり, 将来のスペシャリストとしての 専門性が大きく意識されている。そのため, 必ず しも普通教科「情報」の先に専門教科「情報」が ある，というわけではない。ただ，専門教科「情 報」の科目を普通科で開講することもできるため, 「情報実習」や「マルチメディア表現」等の一部科 目は普通科でも開講されているケースが見られ る。

\section{2 各学校における教科「情報」科目の選択}

東京都教育庁指導部「平成21年度使用教科書教 科別採択結果」2)によると，東京都の公立高等学校 における情報 $A B C$ 教科書採択高校数の割合は, $152: 67: 64$ となっている。現在, 普通科・総合
学科などの普通教科「情報」を設置していると思 われる東京都の公立高等学校は，全日制・定時制 等合わせて約230校であるので, 単純計算をすれば 50校あまりが卒業までに複数科目（例えば1学年に 情報A，3学年に情報Bなど）を設置していることに なる。

研究会等での情報交換の中では，複数科目を設 置している学校は，低学年で「情報A」を全員必履 修，高学年で「情報B」を選択科目にしている学校 が多いように見受けられる。また最近は，入門的 な内容である「情報A」から，情報社会を意識した 「情報C」へと履修科目を変更している学校も見ら れるようになってきた。これらのことを勘案する と, 全員が必履修で受けている科目の割合は，東 京都では，全体を100とすると，平成20年度現在 でおおよそ65：15：20程度と感じている。

\section{3. 授業内容とその工夫}

本校では1学年に「情報A」を2単位置いている。 以下，本校での取り組み(平成20年度年間指導計 画，授業内容，授業の工夫等）を紹介する。

\section{1 年間指導計画}

\subsection{1 全体的な特徵}

本校は前後期の2期制の学校であるが, 年間指導 計画の最大の特徵は, 前後期それぞれの終わりに 大きなプロジェクト型学習（前期：アンケート実 習, 後期 : 総合実習) を置いていることである(図 2，図3）。教科「情報」は，「情報活用の実践力を 高める」という観点から, 学習指導要領にて実習 に割り当てなければならない時間が決められてお り，その割合は，「情報A」が全体の2分の1，「情報 B」「情報C」が全体の3分の1となっている。もちろ 


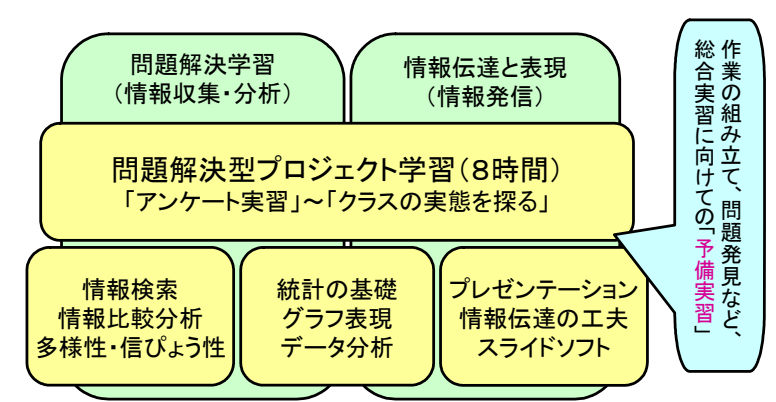

基礎技術·知識 (PC、メールの利用方法とマナー)

図2 年間計画（前期）

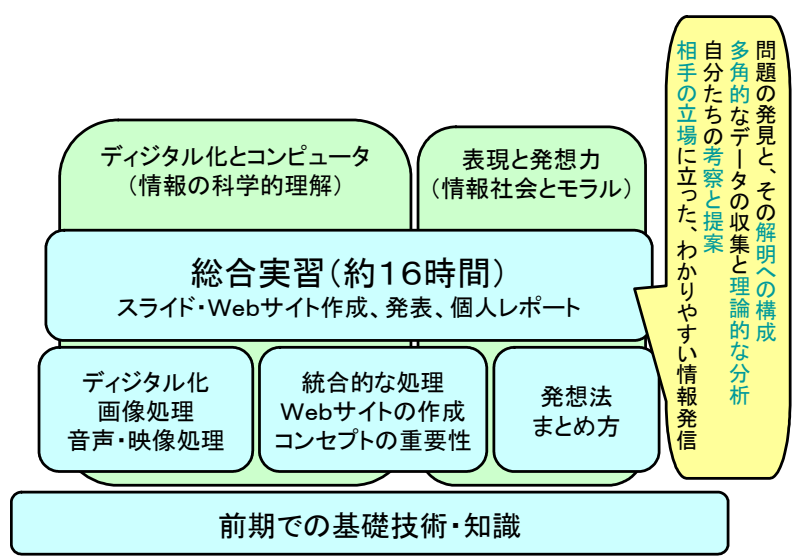

図3 年間計画（後期）

んその時期や方法，形式までは細かく決められて いないので, 本校のように「プロジェクト型学習」 としてまとめているケースもあれば，授業時間単 位で割り当てているケース，また，授業時間内に て部分的に割り当てているケースもあり，ここは 各学校にて工夫しているところである。

ちなみに本校では,「情報A」ということもあり， これらの「プロジェクト」の時間以外も多くの場 面で実習 (グループ学習や調査発表) を取り入れ ている。いわゆる「教科書」「ノート」「黒板」で 終わらせる「講義」としての授業は, 年に数回程 度である。

もう 1 つの大きな特徵が, 年度末「総合実習」を 成功させるための「ステップアップ式スパイラル プログラム」になっているということである。

総合実習では, まさに総合的ないろいろな知識
が要求される。特に本校では,フィールドワーク を重視するとともに，情報を収集したあとの分析， なかでも問題解決における論理的思考力やオリジ ナリティを重視しているため, それを「総合実習」 までに少しずつ繰り返し学習して身につけられる よう組み立てている。

表2に本校での年間計画とキーワードを挙げて おいた。「操作・入力」はPCの操作や文字入力など の基本的な操作方法，「情報態度」はいわゆる「情 報モラル」や「情報の多様性・信ぴょう性」等, 「実験・実地」は，いわゆるフィールドワークなど のインターネット以外から情報を収集してくるも のとお考えいただければと思う。キーワードの種 類等は，特にルールがあるわけではないので参考 程度とされたい。また，その授業と関連があるも のに○をつけておいたが, 厳密なものではなく, ま た，○がついていない箇所でも部分的には取り入 れているところもある。授業の方向性に少しでも イメージを抱いていただければ幸いである。

\subsection{2 前期の進め方}

前期では，問題解決に関連する内容を多くして おり，論理的思考力のトレーニングに力を入れて いる。一番初めは「理想は‥だが，事実は…であ る」という「事実の認識」と「問題の認識」のみ を行う。次の段階では，情報を集め「事実として このようなことがわかる」「なぜこうなっているの だろう」「きっとこうではないか」という簡単な分 析程度までを口頭発表させている。さらに次の問 題解決では，表計算ソフトで適切なグラフ等を表 現させながら，「事実としてこのようなことがわか る」「なぜこうなっているのだろう」「きっとこう ではないか」に加えて「ではどのようにすればそ れが確かめられるのか」といつた解決案まで考え させる。このように，ステップアップをさせなが 
表2 2008年度 情報A 年間指導計画表と授業キーワードー覧

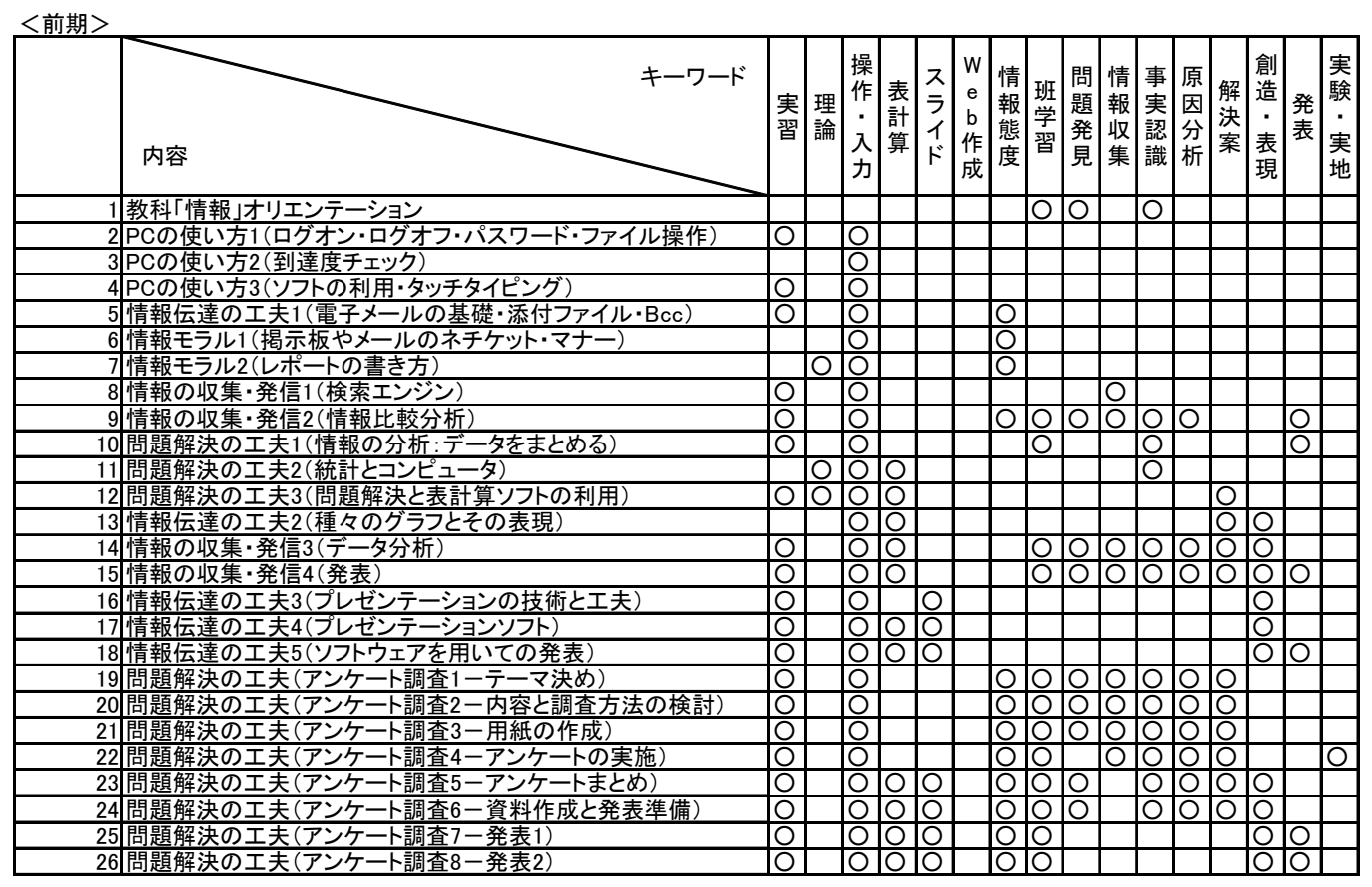

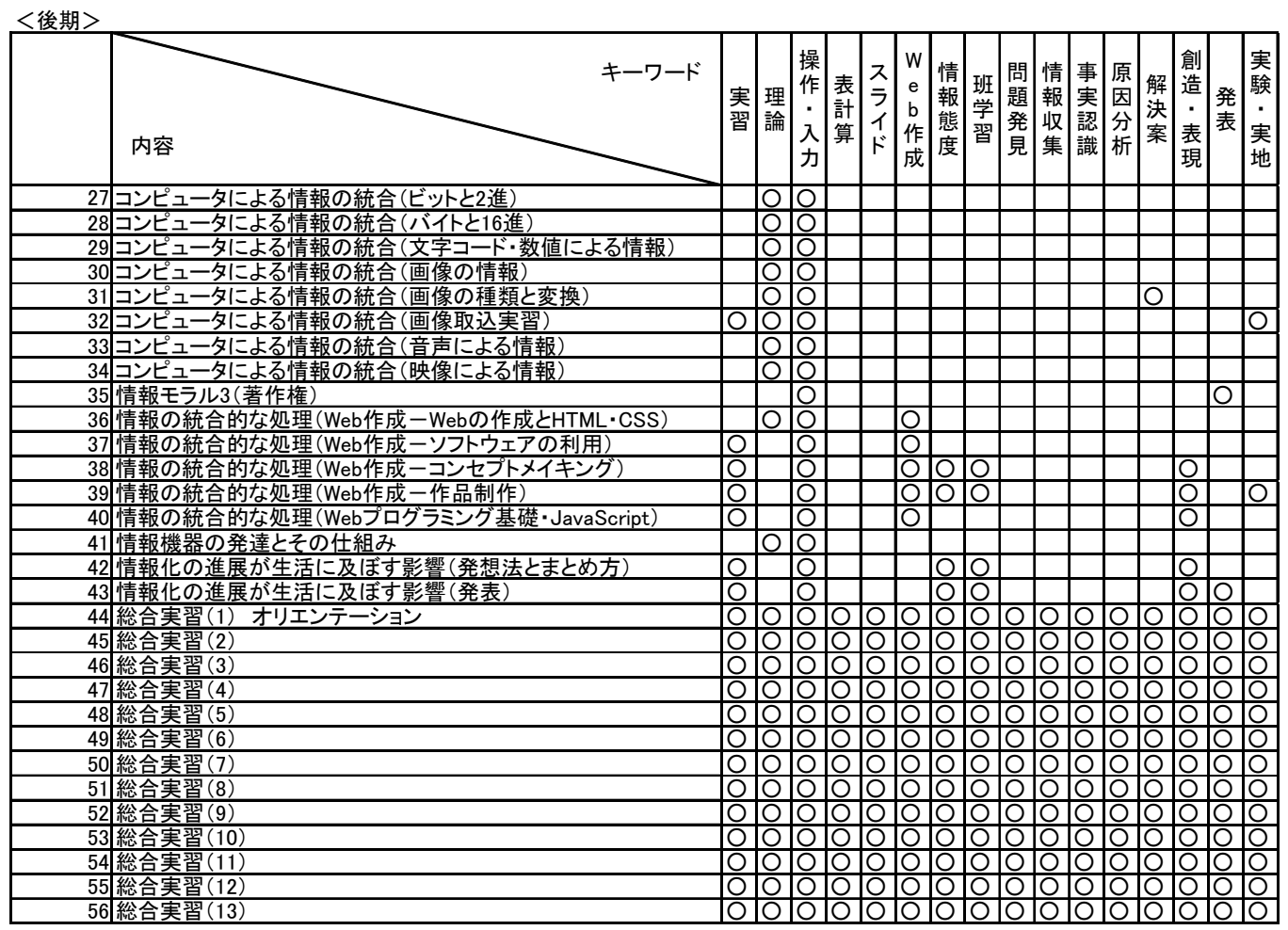

らのスパイラル方式により，論理的思考力の育成 を図っている。この時点では，プレゼンテーショ ン自体にはあまり重きをおいていないため，その 後の「プレゼンテーション」で「情報伝達の工夫」 を意識し，図解の活用やコミュニケーションの特
性そのものについて学習させている。

それらの後に, 前期の総まとめとして「アンケー ト実習」を行う。ここでは, 自分たちのクラスで の疑問点を見つけ，それをアンケート調査で確か め, スライドを使いプレゼンテーションまで行う 
というスタイルをとっている。ここで, 自分たち のカでプロジェクト学習を進めていく難しさ等も 味わってもらうことになるのだが，これが後期「総 合実習」に取り組む上で大変良い経験になってい る。

なお，操作·入力に毎回○がついているが，こ れは，本校では，ワークシートをサーバやWebサ イト上に置き，生徒はそこから電子データをダウ ンロードして直接画面に入力させる方式をとって いるためであり，ほぼ毎時間，日本語入力等の練 習をさせていることになる。中には苦手な生徒も いるが，無理に授業時間内に埋める必要はないこ とを指示しているため, 部分的に手書きでノート にメモをとっている生徒もおり, 各人のペースに 合わせて入力できるように工夫している。タッチ タイピングについては, 学年当初の段階でホーム ポジションや指使い等の基本的な内容を教える が, 後は特に授業では扱わず個人に任せている。ち なみに, 1年後には, ほとんどの生徒が普通の入力 には問題ない程度のスキルを自然と身につけてい る。

このように，前期ではあまりコンピュータに関 する理論的な内容には深入りしないようにしてい る。これは, 1学年前期では, 基本的には中学校で の知識を前提としなければならないためでもあ り，例えばビット・バイト等の内容では，どうし ても数学的な知識 (べき乗や場合の数, n進数など) が必要になってくるからである。逆に，あまり数 学的な内容に立ち入らないことで，いわゆる「文 系」の生徒にも,「情報」の重要さを認識してほし いという思いもある。

\section{1 .3 後期の進め方}

後期では一転して，「ディジタル化」等を通じて の理論的な内容が中心になる。いろいろな情報を
ディジタル化し，画像編集や音楽・動画編集等を 行い，そのメリット・デメリットを考える。著作 権についてももちろん扱う。「ディジタル化によっ て簡単に高度なものが複製できてしまうからこ そ, 最近著作権が問題となってきているのだ」と いう迫り方をし，次のWeb作成へと結びつけてい る。

本校では，情報A「情報の統合的な処理」という 単元の中でWeb制作を実施している。ここでは, ホームページ作成ソフトを利用してのサイト制作 をさせているが，見栄えの良い素晴らしいサイト を作る，というよりも，その中身であるコンセプ トメイキングを重視している。また，グループで 1 つの内容に合わせたWebサイトを構築すること により，総合実習で課している「グループWebサ イトの構築」の練習の場としても役立てている。ま た，生徒に，いわゆる「プログラミング」も体験 してほしいのだが, 情報Aではなかなか適切な単元 がないのが実態であるため, 「Web上でのプログラ ミング」ということで，ここで簡単なJavaScriptを 打ち込ませて体験をさせている。さすがに総合実 習でJavaScriptを活用したサイトを作成したグルー プはまだ見ていないが，生徒のほとんどが非常に 興味を持って体験をしている。

情報化社会の単元では，未来を構築していく存 在である生徒たちに，毎年，ブレーンストーミン グやそれをカテゴリごとにまとめる方法を通じ て,「未来の情報機器（システム）」を考案し，簡 単に発表してもらっている。「批評する」だけでな く, 自分で「考え出す」「創り出す」気持ちを持つ てもらいたい，協力して前向きに進んでいってほ しい, という気持ちがそこにある。毎年，なかな かユニークなものを考えてくれるグループもあ 门，現代の情報化社会も，自然とそうなったので はなく，先人たちが同じようなことを考えて「発 明」してきたこと，ものは見方でずいぶんと变わ 


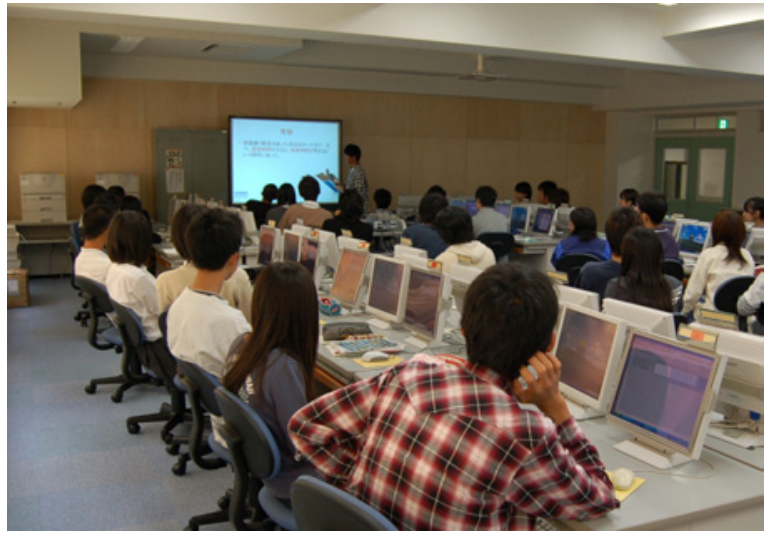

図4 プレゼンテーション

ることなどを理解してもらう良いきっかけになっ ている。

「総合実習」では，1年間の総まとめとして，今 までに学習したすべてのことを行う。問題の発見 からテーマ決め, 解決方法の考案, 解決方法の実 践，フィールドワークも交えてそれを分析し，今 後の課題とともに, Webサイトとプレゼンテー ション（図4）で発表する。配当時間数はクラスに よってばらつきがあるが，およそ15時間前後と なっている。前期に一度プロジェクト学習を実施 しているので, 生徒もその経験を生かし, 上手に 作業を分担し，楽しそうに実習を進めている。

これらの発表を, 校内の他教科の先生方にもご 覧いただき, 生徒の緊張感を高めるとともに, 他 教科での「調べ学習」や「プレゼンテーション」, また「総合的な学習の時間」などに役立てていた だいている。

\section{2 授業内容とその例}

授業の流れと概要については前項にて簡単に述 ベたが，以下，本校で行っている代表的な授業に ついていくつか紹介する。

\subsection{1「情報比較分析」（第9回）}

これは，インターネット上で，二ュースを報じ ている複数のWebサイトを比較し，その違いにつ いて着目し考える，という授業である。ポータル サイトやニュースサイトを利用し，同じ内容を報 じている複数のWebサイトを見つけ，それを比較 する。そして「どこが違うか」という「事実」,「な ぜ違うと思われるのか」という「推測」をグルー プで考え討議し，発表する。

ここには大きく2つの目的がある。1つは，その 進め方を「問題解決」としてとらえ,「事実の認識」 「問題発見」「原因の分析」の3つを意識し，「事実」 と「意見」を明確に区別するということである。も う1つは，人によっていろいろな立場や考え方があ り，同じ情報でもそのとらえ方や表現は多様で あって，それは一概に正しい，正しくないと言い 切れないことを理解することである。

さらには,インターネット上に配信される 二ュースの特徵, 特に,「即時性」や「発信者」に ついても考える良いきっかけになる。例えば，大 きな「事件」があると，まずは事実を素早く伝え るための第1報, 次にいきさつや詳細な情報を交え ての第2報, さらには, 事件を違う角度から報道し たものや，識者の意見を交えた内容などがある。そ れらの二ュースは, 新聞とは違い, 分単位で次か ら次へとネット上に「報道」され，検索サイトに あふれかえってくる上，紙のように劣化しないた め, いつの時点のものなのかは見た目では非常に わかりづらくなっていることもある。また発信者 に関しても，個人と報道機関が同じような形で情 報発信できるため, 信頼できる情報源なのかどう かを見極めることが大切であることも理解でき る。

高校生でも，検索で上位にヒットしたサイトの 内容を鵜吞みにした発表を行ってしまうことが 
時々見られる。実際に, 立場が違ったり内容や二ュ アンスが違うサイトを目の当たりにすることによ り，多くの情報源を確かめることの重要性ととも に，多様な価值観を理解した上で，自分の考えを 固めていくことの大切さを理解してほしいと考え ている。

\subsection{2「種々のグラフとその表現」（第13回）}

「情報伝達の工夫」という内容を意識して表計算 ソフトのグラフ機能を学習する。伝えたい内容を 効果的に伝えるためには，グラフの種類等にどの ような工夫をするとよいのか，また逆に，新聞や 市販のものをサンプルにし，実際に工夫されたグ ラフから情報を読み取る上での注意について考え る。

単に課題を与えてグラフを手順通り作って終わ り，ということではなく，グラフの基本的な作り 方を覚えたら，表現したい内容が効果的に伝えら れるグラフを考えて作成し，同じデータでも重点 的に伝えたい内容によって作成するグラフが変 わってくることを理解する。さらには, 軸が途中 で省略されているケース, 軸の目盛りが違う2つの グラフを比較しているケース, 横幅, 縦幅, 色, 立 体等で差を強調させたりぼやかしたりしている ケースを紹介するとともに，それらのグラフに出 会ったときにデータを見極められるようになるこ と，また逆に自分が伝える側になったとき，それ らを道義に反しない方法で効果的に利用できるこ とをねらいとしている。

\subsection{3「データ分析と発表」（第14，15回）}

インターネット上に共有されているデータを意 識し，それらを効果的に利用するとともに，分析 の基本的な手順について考える授業である。

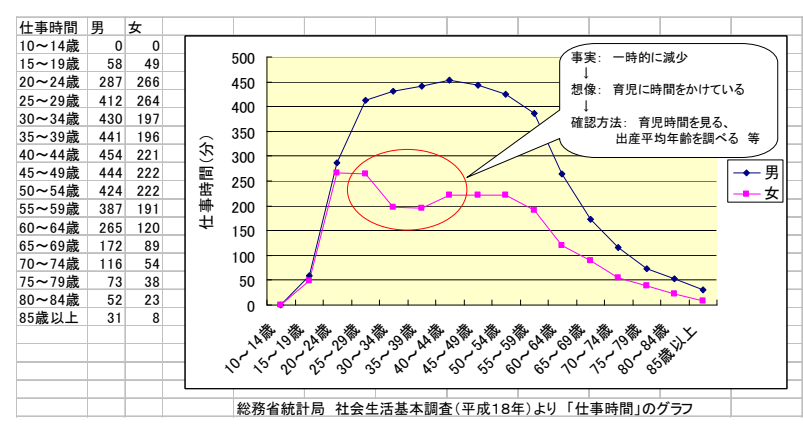

図5 データをグラフ化する

インターネット上にある「統計情報」を検索し てその「ありか」を意識するところから始まり，そ れが表計算データなのかPDFなのかなど, データの 種類や利用方法についてまずは簡単に学習する。 その後, 統計情報が集まっている代表的なサイト として総務省統計局を紹介し，その「社会生活基 本調査」のデー夕3)を利用しながら作業を進めてい $<。$

このデータには，男女，5歳ごとの年代別，仕事 や娛楽等の生活での項目別に費やした時間（分）が 記載されており，生徒はグループでこれらのデー タの一部を抜き出しグラフ化して, グループごと に「そこからわかる事実」「なぜそうなったと思う のかという推測」「それを確かめる手段」を順に検 討し，明確に区別して発表する（図5）。

例えば,「睡眠時間」に着目すると, 横軸に年代, 縦軸に睡眠時間といつたグラフができあがる。例 えば「15歳から19歳の世代では，その前後の年代 と比べて睡眠時間が少ない」等の「事実」が挙げ られ，それに対して，「きっと受験勉強をしている からではないか」という「推測」が，さらに「そ れを確かめる手段」として「勉強時間に関する項 目を調べてみればよい」等といった内容を考えて もらうことになる。さらに余力があるグループで は，例えば「実際に確かめてみたら，20歳〜24歳 までの世代では確かにそれは言えそうだったが, 10歳〜14歳の世代と比べたらそうとは言い切れな 
かった」「生活の変化などで別のことに時間を使い 始めたのではないか」と, 実際に確認させて, さ らに「今後の課題」を考えるようにも指導してい る。

\subsection{4「情報の統合：画像」（第30～32回）}

画像をディジタル化し活用する上で必要な事項 を学習する。大きく分けて次の3つの内容があり, 「光の三原色など色の理論的な面を学ぶ」,「画像を 量子化, 符号化する」, そして, 実際に画像を作成 し「目的に合った画像の加工と画像の形式等を学 ぶ」を3時間かけて行っている。

まずは, 光の三原色に触れる。生徒はいわゆる 色料の三原色については中学校也高等学校の美術 で学んでいるが, 色光の三原色については初めて 学習するため, どの学校でも体験的な内容から入 ることが多いようである。本校では，Web上にあ る色彩関係のサイト4ににてRGBの加法混色を確かめ させているが，筆者の知る学校では，モ二ターや 電光掲示板をルーペ等で拡大して三原色となって いることを確かめさせていたり, RGBそれぞれの三 色の光を出す簡単な装置を作って実際に光を混ぜ 合わせて確認したりしているケースもある。いず れにしても, 生徒は大変興味深く引きつけられて いる (図6)。

画像の量子化，符号化では，A4用紙に5 cm四方 程度の同じ大きさの正方形を6つ描き，そのうち3 つを8dot×8dotに，残りの3つを16dot×16dotに線 を区切る。8dotと16dotそれぞれ1つめの正方形に 同じようなハートマークの線画を描いてもらい, それぞれ2つめの正方形に, 線がかかっているマス を黒く塗りつぶしてもらい, さらにそれぞれ3つめ の正方形に，それぞれ黒く塗りつぶしたマスに1, 塗りつぶしていないマスに0を記載してもらう(図 7)。このようにして, 図形を数值で表すとともに,

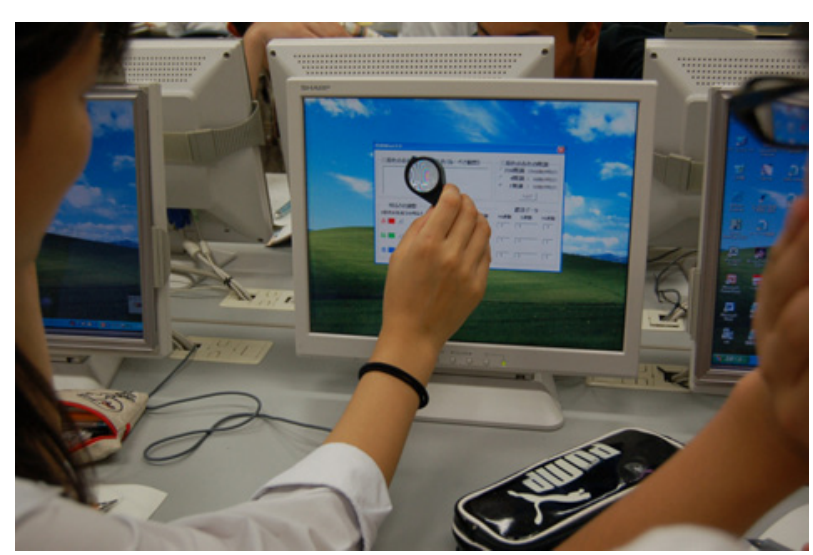

図6 モニターを拡大して三原色を確かめる
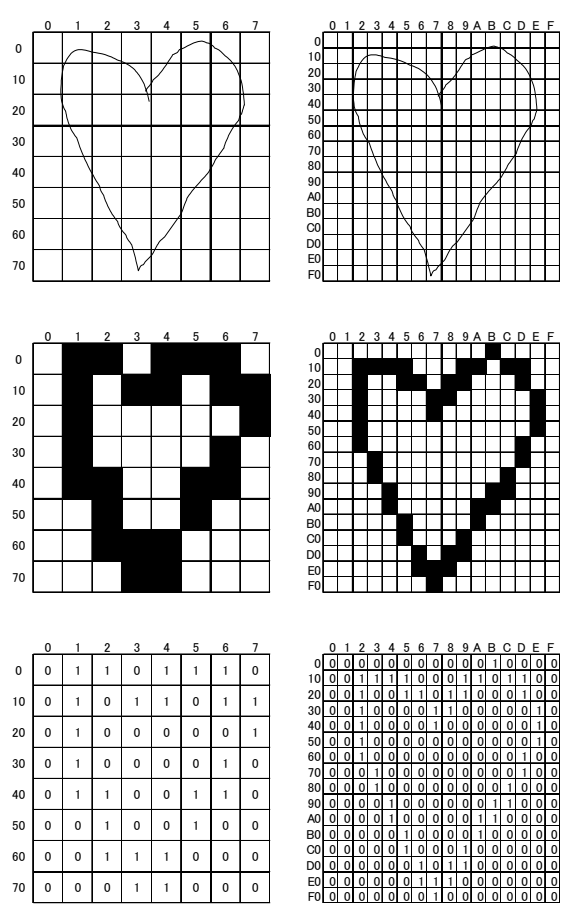

図7 画像の量子化・符号化実習

解像度の高いもののほうがデー夕量が多くなるこ とも理解させている。発展として, カラーの場合 はどうなるのか, どの程度のデー夕量になるのか, また，これらのデータを送信したとき，どの程度 の時間がかかるのか，といったことにも触れてい る。

ある程度の理論的なことがわかったら，実際に ディジタルカメラ等で撮影し大きさを加工した り，目的に応じて圧縮をかけたり，また，加工が 容易ということを知ってもらうためにレタッチ等 
もさせている。これらの内容は著作権を意識させ る上でも重要であり, さらにはWeb作成のときの データ量やサイトに貼り付ける画像の加工という 面で外せない内容となっている。

\section{3 授業の工夫}

効果的な授業を進めるに当たり，年間指導計画 上での工夫については既に述べたところである がほほかにも種々の工夫を施している。ここにそ のいくつかを挙げておく。

\subsection{1 システムの工夫}

現在の高等学校, 特に公立普通科のほとんどは PC室が1つであり，PCを使った実習はすべてその 部屋で実施している。情報科の場合，PCやサーバ 等が扱えると授業の幅が大きく広がったり，便利 な機能を効果的に使うことができるため, 本校で は積極的にサーバや情報通信ネットワークの活用 を行っている。具体的には以下の通りである。

(1)生徒一人ひとりの個人アカウント(ユーザー।D,

\section{パスワード）の発行}

自分のIDとパスワードをしつかり管理すること により，情報化社会において，特にパスワード等 の重要性について意識させている。忘れた者は当 然口グオンできなくなるため,「リセット願い」の 提出亡「身分証明書の提示」を求めている。

(2)サーバの効果的な利用

ユーザーが特定できるため, 個人しか読み書き できないフォルダとともに，特定のグループのみ が読み書きできるフォルダを作り, グループ作業 に生かしている。全員が変更をかけられるフォル ダを利用すると, 誤って移動させてしまったり消 去してしまうこともあり, トラブルの原因になっ ている。また, Webサーバを使うことにより, Web
によるアンケートや授業評価等も取り入れるよう にしている。

\section{(3)アクセス記録の管理とPC室の開放}

本校では，昼休みや放課後にPC室を開放し生徒 に自由に使わせている。しかし，何の手立てもな くPC室を開放すると，不適切な書き込みや不正利 用の温床となってしまうこともある。とはいえ, まったく開放しないとなると, 他教科や自主学習, 課題学習の面で大きなマイナスとなってしまう。

そこで，校内から外部へのWebアクセスを中継 するプロキシサーバを利用し，どの生徒がどの日 時にどんなWebアクセスを行ったのかを記録し， さらにその一部を生徒に見せて教育することを通 じて, 正しく利用してもらう動機付けをしている。

\subsection{2 授業形態の工夫}

コンピュータによる実習を積極的に取り入れて いく必要があるため, 授業形態にも工夫が必要で ある。

（1)週2時間の授業を，1時間ずつ週2回行う。

「情報」は実習を多く行うため，一般的に2時間 の授業を連続で行っているケースが多く見られる が，本校ではそれをあえて1時間ずつ行っている。 これには一長一短があるが，2時間連続だと週に1 回のため, 学校行事や祭日が入ると, 場合によっ ては3〜4週間授業がないということもあり，生徒 の知識や技能の定着という面で大きなマイナスと なってしまうと私は考えている。そのため, チャ イムが鳴ったら直ちに始めることはもちろん，PC が起動中であることを見越して，始めは教科書の 読み合わせをしたり, ペーパーの課題を行ったり と，授業の構成に工夫を施している。

(2)生徒がつまずかないような操作方法の展開と雾 囲気づくり

自治体によっては複数教員で1つの授業を見る 
こともあるが, 一般的には生徒40人に対し教員1名 で授業を行っている。当然, 操作がわからなかっ たり機械がフリーズしたりすると，教員は対応に 追われるため，授業がそこでストップしてしまう。 そのため, 基本操作を記したマ二ュアルの用意や, わからないことを教えあってもよい雾囲気づくり とともに，安易に他人に頼らず自分で解決できる ように, 重要な点は積極的にメモをさせ，自分が 一人で行う場面と教えあってもよい場面を明確に 区別して授業を行っている。

\section{(3)グループ学習や相互評価の活用}

教科「情報」は「コミュニケーション」に深く 関わっている。当然，人間同士のリアルなコミュ 二ケーションが円滑でないと，ネットワークを介 したコミュニケーションもうまくいかないケース が多い。そのため, グループ学習をたくさん取り 入れることにより，互いに教えあったり，協力し 合って作業を進めることの大切さを理解してもら うようにしている。さらには，相互評価を行うこ とによって第三者からの意見を積極的に生徒本人 に還元し，自らの改善の材料とさせている。

\subsection{3 教材の工夫}

「情報」の特徵を生かし, 公開上特に問題がない ものは，授業の内容とともに授業で行う教材をイ ンターネット上のWebサイト5)に公開し自宅でも 学習できるように配慮をしている。また, 不適切 語フィルタリング付き電子メールシステムを外部 業者と契約し，生徒一人ひとりにインターネット 上で利用できる電子メールアカウントを発行する とともに, 授業の導入を電子メールで行っている。

\section{4. 将来に向けての課題}

実践事例をいくつか紹介してきたが，高等学校 でのいわゆる「未履修問題」に代表されるように, これらの授業内容がすべての学校で行われている とは限らない, ということをまず述べておきたい。 本校生徒は理解度も高くよく指導に従うこともあ り，また，他教科教員の「情報科」に対する理解 も非常に高いために実現できていることも多々あ るのが現実である。以下，これらのことも含め将 来に向けての課題を挙げたい。

\section{1 カリキュラム}

「情報A」「情報B」「情報C」は，導入は違うが内 容的には重複する，という箇所が多くあるのも事 実である。そのため, 低学年で「情報A」を学習し た生徒が，興味を持って高学年で「情報B」や「情 報C」を選択するとなると, どうしても内容を精選 させたものにならざるを得なかったり，また，専 門教科「情報」の科目を設置せざるを得ない状況 である。数学や理科のように, | (必修) $\rightarrow \|$ (選択) のようなある程度の階層構造があり, その内容も, 大学での必要知識や大学受験等を意識して高度化 していくなど，大学とのつながりを意識したカリ キュラムを考えていく必要性があるように感じて いる。

\section{2 生徒の状況と小中学校との連携}

学習指導要領では, 小中学校においても情報活 用能力育成のために積極的にコンピュータを利用 するように記されているが，現実的には多くの課 題があるように思われる。

小学校では「情報」に対応する教科科目がなく， 強いて言えば「総合的な学習の時間」での利用が 
挙げられるが，必ずコンピュータを使わなければ いけないというわけではない。さらに「教科担任 制」ではないため, 小学校のカリキュラムや教員 の考え方によりコンピュータ利用の有無に大きな 差が生じてしまい，利用してきた生徒としてこな かった生徒の差が大きい。

また中学校では，「技術」の情報分野では内容が 選択となっていることもあり, 生徒によって学習 してきた内容がまちまちであるため, 結果的に, 高 等学校でもう一度学習を行わなければならない状 況がよく見られている。また，中学校ではあくま でも教科「技術」であり，中学校技術科の先生方 は「技術科の目標」の中で他分野とともに「情報」 という分野を意識されるため, 高等学校教科「情 報」の先生方とは意識の上で若干違いがあるよう に感じることもある。

このように，生徒の理解度や身につけている技 能が毎年大きく変化する中で，高等学校の授業内 容も毎年その都度再検討する必要があり, 教員も 授業の修正等で頭を痛めることも多い。小学校, 中 学校とそれぞれの段階で「情報」に関する到達目 標がもう少し明確になり，「これは学習してきた」 という部分がわかりやすくなると，高校での効果 的な授業にもつながっていくのではないかと思わ れる。

\section{3 教科のイメージ}

「情報科」のイメージを聞くと，教員・生徒とも に返ってくる回答が「パソコンの授業」というこ とであり，とりわけ，アプリケーションソフトの 使い方をマスターするようなイメージがほとんど である。もちろん，「積極的にコンピュータを活用 する」という面ではそれはそれで「完全に間違い」 というわけではないのだが，コンピュータの操作 はあくまでも「手段」であり，「目的」ではない。
この「誤解」のために「情報は必要ない」と言わ れたり，また「受験に関係がない」という理由で， 残念ながら「未履修問題」の主役の1つになってし まったように思えてならない。

「情報」は，このように，目的と手段が非常に入 れ替わりやすい教科であると感じている。例えば 「情報伝達の工夫」という目的で「プレゼンテー ションソフト」を扱っていたはずなのに，気が付 いたらソフトの操作を覚えてスライドを作ること 自体が目的になってしまっていたり，また，「情報 の統合的な処理」,すなわちディジタル化した情報 は統合的に処理できる，ということを学習する目 的でWebサイトを扱っていたはずなのに，見た目 がきれいなWebサイトを作ること自体が目的に なってしまったりする。教科の「イメージ」やコ ンピュータの「おもしろさ」がこのようなことを 引き起こしているのだろう。

「情報」は「知を整理し，統合し，創り出す」こ とを生徒が学習する上で極めて重要な教科だと私 は確信しているが，道具をある程度使えなければ 良い仕事ができないように，パソコンの操作があ る程度できなければ，良い情報活用を行うのが難 しいこともまた事実である。その意味で，操作方 法を学習することは決して否定しないが，操作方 法だけを学習すればよい，という誤解は一日も早 く解き, 教科「情報」のイメージを変えていく必 要があると私は感じている。

\section{4 システムの維持・管理}

「教科のイメージ」にもあるように，「情報の教 員」は「街のパソコンスクールの先生」というイ メージが強いせいか，校内にあるICT機器やコン ピュータの管理を当然のように任されるケースが 多い。さらには, PC室のサーバやコンピュータの 維持・管理も当然のごとく任されることが公立高 
校ではよく見られるケースである。確かに八ード ウェアやソフトウェアに関する知識をお持ちの方 が多いだろうが，「教員」の本務はあくまでも生徒 の教育を司ることである。これだけICT化が進み, 多くの機器が導入されてきている現在, システム の維持や管理, 他の教員への利用教育等は, 専門 のエンジニアやインストラクターに現場をフォ ローしていただける可能性を，国策として法的整 備も含めてぜひ検討していただけたらと強く感じ ている。

\section{5. 終わりに}

よく「教科『情報』はそのうちなくなる」とい う話を耳にする。また，「実践事例が少ない」とか 「授業内容が確立されていない」等という話もよく 聞こえてくる。さらには，教科「情報」を名指し で「生徒間の能力差拡大傾向で，2単位70時間の2 分の1, 3分の1以下の時間で習得できる生徒もかな りいる」ため「必履修から外して選択教科に」と いう主張をされている団体もある。特に最後の主 張に関しては，教科「情報」を忠実に指導しよう としている現場の私にとって，「2分の1，3分の1以 下の時間で習得できる生徒がかなりいる」という のはまったく信じられない状況であり，困惑を隱 し得ない。

まだ教科「情報」が始まって間もないころ，あ る大学の先生から「高等学校『情報』での夕ッチ
タイピング授業」についてお尋ねいただいたこと があった。タッチタイピングの是非についての議 論は別にして,「タッチタイピング」あるいはそれ に代わる言葉は，「情報」の学習指導要領には含ま れていないこと, そして,「情報」で学習する内容 の項目についてご説明したところ，「『情報』では そんなに難しいことを学習するのですか！？」と たいそう驚かれたことが非常に印象的であった。 内容が高度で多岐にわたっていることは私も現在 でもまったく同意見であり，学習指導要領にある 「情報」を忠実に行うと，時間も70時間ではとても 足りないことは明らかだと感じている。

5年間の蓄積により実践事例も増えてきた。「情 報」はその言葉の多様性から,ついつい自分の 「フィルター」で教科の内容を見てしまいがちであ るように感じるが，学習指導要領に書かれている 教科「情報」は実に奥が深く，読むたびに「新し い発見」があるようにも感じている。「授業内容が 明確でない」というよりもむしろ相当詳細に書か れてあり, まずはみんなで学習指導要領をしつか りと「読み込む」ことが実は必要なのではないだ ろうか。私自身は,「現在の高校生に必履修とさせ るべき内容」と思っているが，十分に読み込んだ 上で，その内容が本当に「高校生には必要ではな い内容」なのか，「必要だが他教科で担保される内 容」なのか，「高校生に必要な教科として必履修に する」のが適当か，等という議論を進めるべきで はないのかと感じている。

\section{参考文献}

1) 文部省. 高等学校学習指導要領解説 : 情報編. 開隆堂, 2000, 223p.

2) 東京都教育委員会. 平成21年度都立高等学校用教科書の採択結果について. 2008. http://www.kyoiku.metro.tokyo.jp/press/pr080828s.htm, (参照2008-09-19).

3）総務省統計局. 平成18年社会生活基本調査 調査の結果 統計表一覧 生活時間編（全国）. http://www.stat.go.jp/data/shakai/2006/h18kekka.htm, (参照2008-09-19). 
4）“色の三原色” . TOM's Web Site. http://tomari.org/main/applets/iro/gen.html, (参照2008-09-19).

5）小原格. 情報科準備室入口. http://www.johoka.info/, (参照2008-09-19).

\section{著者抄録}

高等学校で必履修教科として行われている新教科「情報」について, その科目の内容, 具体的な授業内容, 授業を進めていく上での工夫，および課題について，実際に教科指導に当たつている教員より実践に基づ いた形で報告および問題提起を行う。年間指導計画に基づき，少しずつステップアップを繰り返しながら 「情報活用能力」の向上および「問題解決」学習を行い, 最終的に問題解決型プロジェクト学習を成功させ ている具体的な例を紹介するとともに，「『目的』と『手段』が混同されやすい」「教科の主たるイメージが 『操作学習』となってしまっている」という教科「情報」独特の問題点を指摘し, 高等学校で行うべき教科 「情報」についての問題提起も行う。

キーワード

教育, 高等学校, 教科「情報」, 授業実践, 問題解決, プロジェクト学習, 情報活用能力, 学習指導要領

\section{Author Abstract}

"Information Studies" is a required subject at senior high schools. A teacher in high school introduces the idea of subject, actual contents of the subject, tips for class management, and its problem. Based on the annual syllabus, the curriculum focuses on the improvement of "the information utilization ability" and to learn "problem-solving skills" through repetitive process for step-by-step learning. The author also points out the typical problems in the subject caused by confusing "means" with "purposes", misunderstanding the purpose of the subject as "learning how to operate a computer", and some possible solutions are posed.

\section{Key words}

education, high school, Information Studies, class practice, problem-solving skills, project learning, information utilization ability, curriculum guidelines 